NB: This is a preliminary version of Naumov, N. (2017) Burgas. In Dwary. L. (Ed.) The SAGE International Encyclopedia of Travel \& Tourism. London: SAGE (forthcoming in June 2017).

\title{
Burgas, Bulgaria
}

Burgas (also written as "Bourgas") is one of the largest cities in Bulgaria, located on the southern part of the Black Sea coastline. The city serves as a gateway to many summer resorts such as Sunny Beach, Nessebar and Pomorie but is rarely considered as a tourism destination in its own right. However, during the last few years, tourism has become a priority for destination development and a number of new attractions have emerged. The infrastructure has been developed, the airport and sea port have been expanded with new terminals as well as the number of cultural events, festivals and visitor attractions.

\section{Burgas as a tourism destination}

Burgas is popular summer tourism destination, mainly for sun, sand and sea lovers. The geographic location of the city, the favourable climate and good transport links make Burgas an attractive place for recreation, sport and business. Despite its numerous attractions, however, the city is overshadowed by the nearly located summer recreational resorts and holiday villages. Most tour wholesalers prefer to organise their travel packages in Sunny Beach or Nessebar and only include an optional shopping tour of Burgas. However, since Bulgaria joined the European Union, Burgas has successfully implemented a number of strategies, policies and projects to diversity its tourism products and to attract more visitors. One of the most notable projects is the development of the city as an important destination for festival tourism. The Sand Figures Festivals, for example, is held every year during the summer months. Sculptures from all over the world present figures related to particular theme, which is different every year. International Folklore Festival is also increasingly popular. Organized by the Municipality of Burgas, the festival features folk dances and songs and include performances of more than 18, 000 participants. "Spirit of Burgas" is undoubtedly the most popular festival in the city and the one, which has put the Burgas on the map of international music events. Conducted since 2008, the festivals is the most popular music event in the city and has won several national and international awards. "Burgas and the Sea", a Bulgarian pop music festival and "Flora", a flower exhibition event, are also very popular among local residents and domestic visitors.

The culture and heritage of Burgas are exhibited in the Regional Historical Museum of Burgas. The museum is divided into four collections (archaeological, ethnographic, nature and historic) which are exhibited in different buildings in the heart of the city centre. The history of Burgas, archaeological findings from Middle Ages and a good collection of articles regarding the maritime history of the city are presented. Another point of interest is the City Art Gallery. Located in the building of the former Jewish synagogue and designed by Italian architects, the gallery presents the work of many contemporary artists from Burgas, classic art works by Bulgarian classics, and the largest collection of icons from the region of Strandzha Mountain.

The religious heritage of Burgas is another point of interest. The "St Cyril and St. Methodius" cathedral church is the largest one in city and one of the main landmarks in the city centre. 
Designed by the Italian architect Rikardo Toskani, the church was built during the period 18971907 and was declared a monument of culture in 1979. Catholic, protestant and Armenian churches can also be found in various parts of the city.

Religion and history are also the main themes in the newest attraction in Burgas - the island of St Anastasia. Known as "Bolshevic" during the socialist era, the island has a rich and controversial history. Widely known as a religious place with remains of a small monastery, the island was used as a prison in the past. Before 1989, there was a small museum dedicated to this theme. After 1989, the island was almost abandoned, but it was successfully restored as a tourism attraction in the summer of 2014. The local municipality restored the church and the museum and even re-opened the fish restaurant and a small guesthouse. The original story of the island is now used as a main interpretation - the cult to St Anastasia and religious heritage is promoted instead of socialist history of the place.

\section{Promotion and planning}

Tourism is among the main vehicles for economic development of Burgas and as such, is promoted widely. Burgas exhibits in all national tourism fairs and often features in some international tourism events in London, Berlin, Moscow, Bucharest and Tel Aviv. Recreational tourism is the top product of the city but festivals, cultural exhibits and eco-tourism have increasingly been promoted. The re-building of the shipyard and the opening of the new cruise passenger terminal have also promoted Burgas as a future cruise tourism destination.

The role of local government is worth mentioning when we discuss the development of the city. Almost the entire city centre has been reconstructed and new recreational spaces have been created as a part of the new urban planning strategy. The Sea Garden, one of the landmarks of the city, has been improved with the reconstruction of the bridge and the re-building of the old casino - an iconic building, which now serves as a cultural and art centre. Various temporary exhibitions, archaeological and ethnographic collections are exhibited in the museums and cultural events are often organised. The willingness of local government to enhance the image of the city as a tourism destination was also exemplified with the nomination for the European Capital of Culture 2019. Although the city was not selected in the last stage of the national contest, the nomination included a number of new projects, which will surely improve the tourism facilities and attract new tourist markets.

\section{See also: Bulgaria; Sofia, Bulgaria}

Nikola Naumov

King's College, London 